\title{
Research on the Relations between Exhibition Industry and Urban Industrial Structure Adjustment based on the VAR model
}

\author{
DU Zewen ${ }^{1,}$ a , Guo Haixia ${ }^{2, ~ b}$ \\ ${ }^{1}$ Post Doctoral Mobile Station for Business Administration, Harbin University of Commerce, Harbin 150028, \\ China \\ ${ }^{2}$ School of Management, Harbin University of Commerce, Harbin 150028, China \\ adzw03921@163.com, b102049@hrbcu.edu.cn
}

Keywords: Exhibition industry; Urban industrial structure adjustment; Johansen-Juselius test; VAR model.

\begin{abstract}
Exhibition industry is an important way to promote urban industrial structure adjustment. Based on the statistical data from 1978 to 2012 of Guangzhou, the paper selects three variables: exhibition industry, the second industry production value proportion and the third industry production value proportion. Then this paper studies the correlation between exhibition industry and industry structure adjustment of Guangzhou based on VAR model. The results indicate that there exists a long term and balanced relationship between them; Comparing with secondary industry of Guangzhou, exhibition industry has largely promoted to third industrial structure adjustment. Therefore, development of exhibition industry can promote upgrading of industrial structure.
\end{abstract}

\section{Introduction}

Accelerating the adjustment of industrial structure is the main direction of China's transformation of economic development mode during the "13th Five-Year Plan" and is an objective requirement for ensuring the growth of "intermediate high-speed" [1]. Exhibition industry can promote the adjustment and upgrading of the urban industrial structure. The Ministry of Commerce mentioned the important role of exhibition industry in promoting industrial restructuring and accelerating the transformation of economic development. Exhibition industry has a long industrial chain and a large industrial relevance, with cohesive effects, brand effects and radiation effects. Exhibition industry can promote the development of tourism, catering and other related industries, and then promote the adjustment and upgrading of the urban industrial structure. Existing scholars have done a lot of research on exhibition industry and urban industry [3-5], but there is still no quantitative theoretical support for how to use the exhibition industry to promote urban industry adjustment. Therefore, this paper studies the relationship between exhibition industry and urban industrial structure adjustment based on VAR model.

\section{Model Design and Data Source Description}

\subsection{Model Design.}

The vector autoregressive model (VAR model) is a most commonly used econometric model for dealing with multiple relevant economic indicators and predictions [6]. This model can explain the impact of economic shocks on economic variables [7]. This paper will analyze the two-way mechanism of exhibition industry and urban industrial structure adjustment based on the VAR model.

\subsection{Data Source Description.}

The variables in this paper are mainly exhibition industry variables and urban industrial structure adjustment variables. In view of the small impact of the primary industry on exhibition industry, the 
urban industrial structure adjustment variables are mainly expressed by the proportion of the secondary industry's output value and the tertiary industry's output value. This paper takes Guangzhou as an example for empirical analysis. The sample interval is 1978-2012. Considering the important position of the Canton Fair in Guangzhou's exhibition industry (in the past, the annual growth rate of Guangzhou's exhibition industry's operating income has been 18\%) [8], using the spring turnover of the Canton Fair as a measure of the Guangzhou exhibition industry, recorded as CJE; Guangzhou's industrial restructuring variables are expressed as the proportion of the secondary industry in GDP and the proportion of the tertiary industry in GDP, and are recorded as $\mathrm{C}_{2}$ and $\mathrm{C}_{3}$, respectively. The data comes from the Guangzhou Statistical Information Network and the official website of the China Import and Export Fair. In order to avoid the violent fluctuation of the data and the heteroscedasticity in the sequence, the variables are logarithmically processed, which are respectively recorded as $\mathrm{LNCJE}, \mathrm{LN} \mathrm{C}_{2}$, and $\mathrm{LN} \mathrm{C}_{3}$.

\section{Empirical Analysis}

\subsection{Stability Test of Variables.}

The unit root test is very important for the stability of the test time series. Otherwise, the pseudo-regression phenomenon will occur when the VAR model is established by using non-stationary time series. In order to avoid the invalid conclusion caused by the pseudo-regression problem, this paper uses the augmented Dickey-Fowler test method (ADF) to judge the stability of the regression variables. With the help of Eviews6.0 software, the test results are shown in Table 1, in the table $\mathrm{D}\left(\mathrm{LNC}_{2}\right), \mathrm{D}\left(\mathrm{LNC}_{3}\right)$, and $\mathrm{D}$ (LNCJE) represent the first-order difference sequence of the corresponding variable, respectively.

Table 1 Results of ADF test for the stability of each variable

\begin{tabular}{|c|c|c|c|c|}
\hline Variable & ADF test value & $5 \%$ critical value & Test form $(\mathrm{C}, \mathrm{T}, \mathrm{L})$ & Is it smooth? \\
\hline $\mathrm{LNC}_{2}$ & -2.836778 & -3.548490 & $(\mathrm{C}, \mathrm{T}, 0)$ & No \\
\hline $\mathrm{LNC}_{3}$ & -2.523363 & -3.548490 & $(\mathrm{C}, \mathrm{T}, 0)$ & No \\
\hline LNCJE & -3.005450 & -3.548490 & $(\mathrm{C}, \mathrm{T}, 0)$ & No \\
\hline $\mathrm{D}\left(\mathrm{LNC}_{2}\right)$ & -4.419725 & -3.557759 & $(\mathrm{C}, \mathrm{T}, 1)$ & Yes \\
\hline $\mathrm{D}\left(\mathrm{LNC}_{3}\right)$ & -4.961476 & -3.557759 & $(\mathrm{C}, \mathrm{T}, 1)$ & Yes \\
\hline D(LNCJE) & -5.393341 & -3.557759 & $(\mathrm{C}, \mathrm{T}, 1)$ & Yes \\
\hline
\end{tabular}

Note: In the test form (C, T, L), C, T, and L represent constant term, time trend, and lag order, respectively.

It can be seen from the test results Table 1 that $\mathrm{LNC}_{2}, \mathrm{LNC}_{3}$, and LNCJE are non-stationary sequences at a $5 \%$ significance level. After the first-order difference, the data ADF test values of the three variables are smaller than the critical value of $5 \%$ of the significance level, indicating that they are all stationary, which is a first-order "single-integrated" time series, which satisfies the precondition of cointegration test.

\subsection{Cointegration Test.}

For the cointegration relationship of the above three variable time series, the Johansen-Juselius cointegration test was used, and the results are shown in Table 2.

Table 2 Multivariate Johansen cointegration test results

\begin{tabular}{ccccc}
\hline Original hypothesis & eigenvalue & trace statistic & 5\% critical value & P value \\
\hline 0 cointegration equations * & 0.616440 & 38.45064 & 29.79707 & 0.0040 \\
At least 1 cointegration & 0.245047 & 8.744596 & 15.49471 & 0.3895 \\
$\begin{array}{c}\text { equation } \\
\text { At least 2 cointegration } \\
\text { equations }\end{array}$ & 0.000984 & 0.030504 & 3.841466 & 0.8613 \\
\hline
\end{tabular}

Note: * indicates a 5\% significance level test.

From the cointegration test results table 2 , it can be seen that at the $5 \%$ significance level, there is 
only one trace statistic (38.45064) with a critical value (29.79707) at a significance level greater than $5 \%$. This result indicates that there is a unique cointegration relationship between $\mathrm{LNC}_{2}, \mathrm{LNC}_{3}$, and LNCJE. Therefore, the standardized cointegration equation is: LNCJE $=32.10651+9.124143$ $\mathrm{LNC}_{2}+12.87133 \mathrm{LNC}_{3}$. It can be seen from the above equations that the proportion of the output value of the secondary industry in Guangzhou and the proportion of the output value of the tertiary industry are in the same direction as exhibition industry, and the influence of the tertiary industry on exhibition industry is greater than that of the secondary industry.

\subsection{Determination of Lag Order of VAR Model.}

The $\mathrm{LNC}_{2}, \mathrm{LNC}_{3}$, and LNCJE are used as endogenous variable sets to establish a VAR model. Since the variables are clear, it is important to determine the lag order of the model [6]. The method of information criterion is used to determine the lag order $\mathrm{p}$ of the VAR model. Under the condition of unconstrained vector autoregressive VAR model, the lag order Lag is tested one by one, and the values of AIC and SC corresponding to 1 to 3, the minimum AIC and SC corresponding p value can be used as the lag order of VAR model. The test results are shown in Table 3 below.

Table 3 Judgment of lag order of VAR model

\begin{tabular}{ccccccc}
\hline Lag & LogL & LR & FPE & AIC & SC & HQ \\
\hline 0 & 64.42290 & NA & $4.32 \mathrm{e}-06$ & -3.838931 & -3.701518 & -3.793383 \\
1 & 128.7178 & $112.5162^{*}$ & $1.37 \mathrm{e}-07^{*}$ & $-7.294865^{*}$ & $-6.745214^{*}$ & $-7.112671^{*}$ \\
2 & 131.0943 & 3.713203 & $2.11 \mathrm{e}-07$ & -6.880893 & -5.919004 & -6.562054 \\
3 & 137.5099 & 8.821520 & $2.59 \mathrm{e}-07$ & -6.719371 & -5.345244 & -6.263887 \\
\hline
\end{tabular}

Note: “*” indicates that the lag order corresponding to the row of the marked value is the best lag order recommended by the test standard for the column in which the value is located.

It can be seen from Table 3 above, the optimal lag order of the VAR model is 1 .

\subsection{Determination of Stationarity of VAR Model.}

In order to test the stationarity of the VAR (1) model, the AR root chart method is used. The test results are shown in Fig.1. The reciprocal values of all the eigenvalues of the VAR (1) model are located in the unit circle, indicating that the structure of the model is stable. It can be used to study the continuous relationship of dynamic changes between the variable $\mathrm{LNC}_{2}, \mathrm{LNC}_{3}$ and LNCJE.

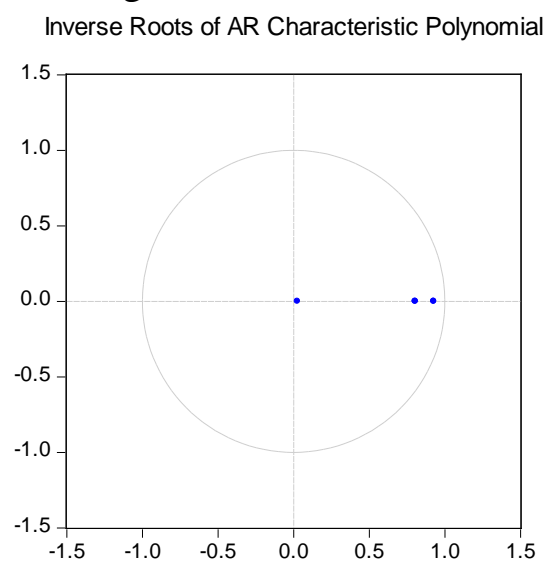

Fig.1 AR root test chart

\subsection{Granger Causality Test.}

The Granger causality test is used to analyze the causal relationship between economic variables. In order to verify whether there is a causal relationship between exhibition industry and the urban industrial structure adjustment, and further verify the relationship between exhibition industry and the urban industrial structure adjustment, this paper conducts the Granger causality test. The test method is as follows: the variables of exhibition industry and the proportion of the output value of the secondary industry in Guangzhou are included in a group, and the variables of exhibition industry and 
the proportion of the output value of the tertiary industry are included in a group. The lag period is 1 , and the test results are shown in Table 4.

Table 4 Granger causality test results

\begin{tabular}{cccc}
\hline Original hypothesis & sample number & F statistical value & P value \\
\hline LNCJE is not the Granger cause of $\mathrm{LNC}_{2}$ & 34 & 5.380041 & 0.0204 \\
$\mathrm{LNC}_{2}$ is not the Granger cause of LNCJE & 34 & 2.630046 & 0.1049 \\
LNCJE is not the Granger reason for LNC & 34 & 6.784264 & 0.0092 \\
$\mathrm{LNC}_{3}$ is not the Granger reason for LNCJE & 34 & 6.018090 & 0.0142 \\
\hline
\end{tabular}

It can be seen from Table 4 of the test results that under the $5 \%$ significance level, when the lag order is 1 , there is a one-way causal relationship between the Guangzhou's exhibition industry and the proportion of the output value of the secondary industry. Guangzhou's exhibition industry is the Granger reason for the proportion of the output value of the secondary industry. The proportion of the output value of the second industry in Guangzhou is not the Granger reason for its exhibition industry. There is a two-way causal relationship between the Guangzhou's exhibition industry and the proportion of the tertiary industry's output value. This conclusion shows that in the process of Guangzhou's exhibition industry development and industrial structure adjustment, the development of exhibition industry will lead to structural adjustment of the secondary and tertiary industries. The exhibition industry promotes the optimization and upgrading of the industrial structure, and the optimization of the tertiary industry structure will also promote the development of the exhibition industry.

\section{Conclusions}

Taking Guangzhou as an example, this paper uses the econometric model to empirically analyze exhibition industry and urban industrial structure adjustment, and obtains the following conclusions: First, from the results of ADF test, the sequence data satisfies the first-order single-order and meets the conditions of cointegration test. Second, from the Granger causality test results, there is a one-way causal relationship between the Guangzhou's exhibition industry and the proportion of the output value of the second industry. There is a two-way causal relationship between the Guangzhou's exhibition industry and the proportion of tertiary industry output value. In response to the above analysis, this paper proposes: First, the government should further promote the role of exhibition industry in promoting the adjustment of industrial structure. Second, the government should accelerate the development of the exhibition industry.

\section{Acknowledgements}

This work was financially supported by the Heilongjiang Province Philosophy and Social Science Research Planning Project (16GLB09); Harbin University of Commerce Ph.D. Research Project (14RW18); Harbin University of Commerce Project “Modern Service Industry Supporting Longjiang Revitalization Development Research” (hx2016001); 2016 Harbin University of Commerce Youth Innovation Talent Support Project (2016QN009); Harbin University of Commerce's Postdoctoral Research Support Program (2017BSH024).

\section{References}

[1] Guo Xuhong, Li Xuanqi. Research on China's Industrial Structure Adjustment and Upgrading under the New Normal [J]. East China Economic Management, 2016(1): 49-54. (In Chinese)

[2] Schilling K C, Mc Hargue. The Economic Impact of the 2001 Wisconsin State Fair [R]. University of Wisconsin Milwaukee Center for Economic Development (UWMCED), 2002 (3).

[3] Kim Samuel Seongseop, Chon Kaye, Chung Kyu Yoop. Convention industry in South Korea: An Economic Impact Analysis [J]. Tourism Management, 2003(5): 533-541. 
[4] Rboert. Ctiemliit. Alniac Serhat Erat Procedit-social and Behavioral Science [M]. American Economic Review, 2013.

[5] Meng Fansheng, Song Guoyu, Jing Weixue. Influential factors of the development of convention and exhibition industry and empirical research on the impact of urban economy [J]. Technology and Economy, 2012(4): 32-37. (In Chinese)

[6] Wei Yan, Pu Zuoyi. Empirical Study on Industrial Structure Adjustment and Ecological Security Based on VAR Model [J]. Statistics and Decision, 2013(4): 133-135. (In Chinese)

[7] Wu Miaomiao, Liu Cui, Fu Weizhong. Research on the impact of technological innovation based on VAR and DEA on the rise of industrial value chain [J]. Science and Technology Management Research, 2015(13): 201-205. (In Chinese)

[8] Fang Zhongquan, Liu Songping, Lin Wei. Analysis on the Cultivation of Convention and Exhibition Industry Clusters in Pazhou Area of Guangzhou City [J]. Business Research, 2012(9): 212-216. (In Chinese) 